\title{
Comments to: A systematic review of pathological findings in COVID-19: a pathophysiological timeline and possible mechanisms of disease progression
}

\author{
Rafael Parra-Medina $\mathbb{( I}^{1,2} \cdot$ Sabrina Herrera ${ }^{3} \cdot$ Jaime Mejía $^{4}$ \\ Received: 30 June 2020 / Revised: 13 July 2020 / Accepted: 13 July 2020 / Published online: 21 July 2020 \\ (c) The Author(s), under exclusive licence to United States \& Canadian Academy of Pathology 2020
}

\section{To the Editor:}

We reviewed the excellent systematic article published by Pola et al. [1] about the pathological findings in COVID-19. Based on the 250 COVID-19 autopsies found during our systematic review through March 30, 2020; we concur with the article hypothesis of mechanisms of infection and the tissular injury. However, we would like to highlight two topics that the authors did not discuss.

The first, the autopsies findings could support the hypothesis of macrophages hyperactivation. This has already been reported in other coronavirus such as SARS-CoV1 and MERS [2]. In the initial autopsies in COVID-19 patients, the presence of CD68+ macrophages in lung and heart tissues $[3,4]$ and the presence of CD169+ macrophages in lymph node subcapsular spaces and in splenic marginal zone were reported. These macrophages expressed the SARS-CoV-2 entry receptor ACE2 and contained SARS-CoV-2 nucleoprotein [5]. Disorders of macrophages as secondary hemophagocytic lymphohistiocytosis (sHLH) have been reported in COVID-19 [6, 7]. In autopsies, hemophagocytosis has been observed in lung, lymph node, bone marrow, liver, and spleen $[6,8-10]$. sHLH is a hyperinflammatory syndrome characterized by a fulminant and fatal hypercytokinaemia with multiorgan failure. In adults, sHLH is mostly triggered

Rafael Parra-Medina

rafa.parram@gmail.com

1 Department of Pathology, Research Institute Fundación Univeristaria de Ciencias de la Salud, Bogotá, Colombia

2 Department of Pathology, Instituto Nacional de Cancerología, Bogotá, Colombia

3 Department of Pathology Las Américas, Medellin, Colombia

4 Department of Pathology, Instituto de Patologia Mejia Jimenez, Cali, Colombia by viral infections, autoimmune diseases and neoplasms [11], and occurs in 3.7-4.3\% of sepsis cases [12]. The diagnosis of sHLH is based on clinical, laboratory, and morphologic criteria. The main features are: unremitting fever, cytopenias, hepatosplenomegaly, hypertriglyceridemia, hypofibrinogenemia, and hyperferritinemia [13, 14]. Severe COVID-19 could be considered a hyperferritinemic syndrome by the clinical similarities detected [15]. In these conditions, Ferritin plays a critical role in the immune response. The production and secretion of extracellular ferritin is derived from macrophages [16].

The second is the presence of orchitis associated with fibrin microthrombi in COVID-19 patients [10, 17]. This condition has also been reported in cases with SARS-CoV-1 and in other viral infections like hepatitis B and C, mumps, Epstein-Barr virus, HIV, and HPV [18]. The mechanism of orchitis in SARS-CoV-2 is possibly related to the interaction of the virus with the ACE2 receptor. This receptor is expressed in spermatogonia and Leydig and Sertoli Cells [19]. We believe the relationship between hormone levels and testicular compromise deserve further study. Ma et al. reported 81 patients with COVID-19 with testosterone to luteinizing hormone ( $\mathrm{T}$ to $\mathrm{LH}$ ) ratio dramatically decreased in comparison with 100 healthy males $(p<0.0001)$ [20].

\section{Compliance with ethical standards}

Conflict of interest The authors declare that they have no conflict of interest.

Publisher's note Springer Nature remains neutral with regard to jurisdictional claims in published maps and institutional affiliations.

\section{References}

1. Polak SB, Van Gool IC, Cohen D, von der Thüsen JH, van Paassen J. A systematic review of pathological findings in 
COVID-19: a pathophysiological timeline and possible mechanisms of disease progression. Mod Pathol. 2020. https://doi.org/10. 1038/s41379-020-0603-3.

2. Merad M, Martin JC. Pathological inflammation in patients with COVID-19: a key role for monocytes and macrophages. Nat Rev Immunol. 2020;20:355-62.

3. Fox E, Akmatbekov A, Harbert JL, Li G, Quincy Brown J, Vander Heide RS. Pulmonary and cardiac pathology in Covid-19: the first autopsy series from New Orleans. Lancet Respir Med. 2020;8:681-6.

4. Yao XH, Li TY, He ZC, Ping YF, Liu HW, Yu SC, et al. [A pathological report of three COVID-19 cases by minimal invasive autopsies]. Zhonghua bing li xue za zhi $=$ Chinese J Pathol. 2020;49:411-7.

5. Feng Z, Diao B, Wang R, Wang G, Wang C, Tan Y, et al. The novel severe acute respiratory syndrome coronavirus 2 (SARSCoV-2) directly decimates human spleens and lymph nodes. medRxiv. 2020. https://doi.org/10.1101/2020.03.27.20045427.

6. Prilutskiy A, Kritselis M, Shevtsov A, Yambayev I, Vadlamudi C, Zhao Q, et al. SARS-CoV-2 infection associated hemophagocytic lymphohistiocytosis: an autopsy series with clinical and laboratory correlation. medRxiv. 2020.

7. Mehta P, McAuley DF, Brown M, Tattersall RS, Manson JJ. COVID-19: consider cytokine storm syndromes and immunosuppression. Lancet. 2020;395:1033-4.

8. Adachi T, Chong J-M, Nakajima N, Sano M, Yamazaki J, Miyamoto I, et al. Clinicopathologic and immunohistochemical findings from autopsy of patient with COVID-19, Japan. Emerg Infect Dis. 2020;26. https://doi.org/10.3201/eid2609.201353.

9. Bradley BT, Maioli H, Johnston R, Chaudhry I, Fink SL, Xu H, et al. Histopathology and ultrastructural findings of fatal COVID19 infections. The Lancet. 2020.

10. Nunes Duarte-Neto A, de Almeida Monteiro RA, da Silva LFF, Malheiros DMAC, de Oliveira EP, Theodoro Filho J, et al. Pulmonary and systemic involvement of COVID-19 assessed by ultrasound-guided minimally invasive autopsy. Histopathology. 2020;14160. https://doi.org/10.1111/his.14160.

11. Ramos-Casals M, Brito-Zerón P, López-Guillermo A, Khamashta MA, Bosch X. Adult haemophagocytic syndrome. Lancet. 2014;383:1503-16.

12. Karakike E, Giamarellos-Bourboulis EJ. Macrophage activationlike syndrome: a distinct entity leading to early death in sepsis. Front Immunol. 2019;10:55.

13. Gupta S, Weitzman S. Primary and secondary hemophagocytic lymphohistiocytosis: clinical features, pathogenesis and therapy. Expert Rev Clin Immunol. 2010;6:137-54.

14. Debaugnies F, Mahadeb B, Ferster A, Meuleman N, Rozen L, Demulder A, et al. Performances of the $\mathrm{H}$-score for diagnosis of hemophagocytic lymphohistiocytosis in adult and pediatric patients. Am J Clin Pathol. 2016;145:862-70.

15. Colafrancesco S, Alessandri C, Conti F, Priori R. COVID-19 gone bad: a new character in the spectrum of the hyperferritinemic syndrome? Autoimmun Rev. 2020;19:102573.

16. Recalcati S, Invernizzi P, Arosio P, Cairo G. New functions for an iron storage protein: the role of ferritin in immunity and autoimmunity. J Autoimmun. 2008;30:84-9.

17. Buja LM, Wolf DA, Zhao B, Akkanti B, McDonald M, Lelenwa $\mathrm{L}$, et al. The emerging spectrum of cardiopulmonary pathology of the coronavirus disease 2019 (COVID-19): report of 3 autopsies from Houston, Texas, and review of autopsy findings from other United States cities. Cardiovasc Pathol. 2020;48:107233.

18. Xu J, Qi L, Chi X, Yang J, Wei X, Gong E, et al. Orchitis: a complication of severe acute respiratory syndrome (SARS) 1. Biol Reprod. 2006;74:410-6.

19. Wang Z, Xu X. scRNA-seq profiling of human testes reveals the presence of the ACE2 receptor, a target for SARS-CoV-2 infection in spermatogonia, leydig and sertoli cells. Cells. 2020;9:920.

20. L Ma, W Xie, D Li, L Shi, Y Mao, Y Xiong, et al. Effect of SARS-CoV-2 infection upon male gonadal function: a single center-based study. medRxiv. 2020. 